\title{
Localization of genes modulating the predisposition to schizophrenia: a revision
}

\author{
E.Z. Lopes-Machado ${ }^{1}$ and F.A.M. Duarte ${ }^{2}$
}

\begin{abstract}
The genetics of schizophrenia or bipolar affective disorder has advanced greatly at the molecular level since the introduction of probes for the localization of specific genes. Research on gene candidates for susceptibility to schizophrenia can broadly be divided into two types, i.e., linkage studies, where a gene is found near a specific DNA marker on a specific chromosome, and association studies, when a condition is associated with a specific allele of a specific gene. This review covers a decade of publications in this area, from the 1988 works of Bassett et al. and Sherrington et al. on a gene localized on the long arm of chromosome 5 at the $5 q 11-13$ loci, to the 1997 work of Lin et al. pointing to the 13q14.1-q32 loci of chromosome 13 and to the 1998 work of Wright et al. on an HLA DRB1 gene locus on chromosome 6 at $6 \mathrm{p} 21-3$. The most replicated loci were those in the long arm of chromosome 22 (22q12-q13.1) and on the short arm of chromosome 6 (6p24-22). In this critical review of the molecular genetic studies involved in the localization of genes which modulate the predisposition to schizophrenia the high variability in the results obtained by different workers suggests that multiple loci are involved in the predisposition to this illness.
\end{abstract}

\section{REVIEW}

The genetics of schizophrenia and bipolar affective disorder has advanced greatly at the molecular level since the introduction of probes for the localization of specific genes (Botstein et al., 1980). Molecular biology has also been used to localize the genes involved in, among others, conditions such as Huntington's chorea (chromosome 4), Friedreich's ataxia (chromosome 9), cystic fibrosis (chromosome 7) and Alzheimer's syndrome (chromosome 21). Everything indicates that the psychoses and Alzheimer's syndrome are conditions which are precipitated by both environmental and genetic factors. In the specific case of schizophrenia, it is believed that as well as environmental factors many genes (polygenes), distributed on different loci, influence predisposition to the condition, and it appears reasonable to suppose that "the determinants of schizophrenia are multifactorial and polygenic" (FrotaPessoa, 1989).

The molecular level studies on candidate genes exercising some role on susceptibility to schizophrenia can broadly be divided into two types, i.e., linkage studies, where a gene is found near a specific DNA marker on a specific chromosome, and association studies, when an illness is associated with a specific allele of a specific gene.

To gauge whether or not evidence of linkage is statistically significant "lod score" (i.e., the logarithm of the "odds score") values have always to be higher than 3 in pedigrees affected with schizophrenia.

The localization of genes influencing the predisposi- tion to schizophrenia opens great possibilities for the study of the pathogenesis of this psychosis. In the effort to find the genetic basis of schizophrenia many genetic loci have been proposed involving many chromosomes (Table I).

Starting with the work of Sherrington et al. (1988), it was proposed that a gene localized on the long arm of chromosome 5 determined the predisposition to schizophrenia. That is, these authors discovered a locus (5q11-13) occupied by alleles (i.e., modulations of a gene determining opposing traits) which in some families interferred with susceptibility to schizophrenia. These findings, however, along with those of Bassett et al. (1988), were not confirmed by other workers (e.g., Hallmayer et al., 1992; Macciardi et al., 1992; Gurling, 1994), with new evidence suggesting a "schizophrenia locus" (D5S111, 5p14.1-13.1) on the short arm of chromosome 5 (Silverman et al., 1996).

More recently, loci involved in susceptibility to schizophrenia have also been described on chromosome 22 (Pulver et al., 1994a,b; Moises et al., 1995a; Schwab et al., 1995b and Gill et al., 1996) and chromosome 6 (6p24-22) delimited by the markers D6S296, D6S285, D6S274, D6S260 and D6S259 (Straub et al., 1995; Schwab et al., 1995a, Moises et al., 1995b; Wang et al., 1995, 1996), as well as new additional regions on chromosomes 9 and 20 (Moises et al., 1995b) and 3 and 8 (Pulver et al., 1995). In a study of linkage, using 15 markers covering 30 centimorgans of the 8p22-21 region of chromosome 8p, Kendler et al. (1996) suggested that there might be a locus of vulnerability to schizophrenia on this chromosome. Riley et al. (1997) proposed a locus on chromosome 9 (9q34.3), 
Table I - Proposes and localization of genes modulating the predisposition to schizophrenia.

\begin{tabular}{|c|c|}
\hline Author(s) & Proposed loci \\
\hline Sherrington et al. (1988) & Long arm of chromosome 5 at $5 q 11-13$ \\
\hline Crow (1988); Crow et al. (1989); DeLisi and Crow (1989) & Pseudoautosomic locus of the X-Y chromosomes \\
\hline $\begin{array}{l}\text { Pulver } \text { et al. (1994a); Moises et al. (1995a); Schwab et al. (1995a); } \\
\text { Vallada et al. (1995); Gill et al. (1996); Deckert et al. (1997) }\end{array}$ & $\begin{array}{l}\text { Long arm of chromosome } 22 \text { at } \\
\text { 22q12-q13.1, loci D22S278, D22S304, D22S283 }\end{array}$ \\
\hline $\begin{array}{l}\text { Straub et al. (1995); Schwab et al. (1995b); Moises et al. (1995b); } \\
\text { Wang et al. (1995, 1996); Pujana et al. (1997) }\end{array}$ & $\begin{array}{l}\text { Short arm of chromosome } 6 \text { at 6p24-22, } \\
\text { loci D6S296, D6S274, D6S285, D6S260 }\end{array}$ \\
\hline Riley et al. (1997) & Chromosome 9 at $9 \mathrm{q} 34.3$ \\
\hline Moises et al. (1995b) & Proposed additional new regions on chromosomes 9 and 20 \\
\hline Kendler et al. (1996) & Locus of vulnerability on chromosome $8 p$ \\
\hline Pulver et al. (1995) & Chromosomes 3 and 8 ( $3 p$ and $8 p$ ) as "potential loci" \\
\hline Mulcrone et al. (1995) & $\begin{array}{l}\text { Long arm of chromosome } 11 \text {, the gene for the } \\
D_{2} \text { dopamine receptor }\end{array}$ \\
\hline Williams et al. (1996) & $\begin{array}{l}\text { Proposed an association between schizophrenia and } \mathrm{T} 102 \mathrm{C} \\
\text { polymorphism in the gene for the type 2a serotonin receptor } \\
\text { on the long arm of chromosome13 }\end{array}$ \\
\hline Lin et al. (1997) & Chromosome 13 at $13 \mathrm{q} 14.1-\mathrm{q} 32$ \\
\hline Gelernter et al. (1995) & $\begin{array}{l}\text { Proposed linkage studies with the SLC6A4 locus of the gene } \\
\text { for serotonin transporter protein on chromosome } 17 \text { at } 17 \mathrm{q} 12 \text {, } \\
\text { and the D17S73 and D17S58 markers }\end{array}$ \\
\hline Schwab et al. (1998) & Chromosome 18 at $18 \mathrm{p}$ \\
\hline Crocq et al. (1992); Mant et al. (1994); Griffon et al. (1996) & $\begin{array}{l}\text { Chromosome } 3 \text { at } \mathrm{q} 13.3 \text {, the gene for human } \\
\mathrm{D}_{3} \text { dopamine receptor }\end{array}$ \\
\hline Silverman et al. (1996) & Short arm of chromosome 5 at $5 \mathrm{p} 14.1-13.1$, locus D5S111 \\
\hline Shaw et al. (1998) & Chromosomes 1, 2, 4, 11, 13 \\
\hline Wright et al. $(1996,1998)$ & HLA DRB 1 gene locus on chromosome 6 at $6 \mathrm{p} 21.3$ \\
\hline
\end{tabular}

corresponding to the gene for the N-methyl-D-aspartate receptor subunit. Consequently there is in the literature a tendency to admit a heterogeneity of loci (Moises et al., 1995b; Straub et al., 1995; Wang et al., 1995), with Risch (1990) suggesting a group of interacting loci in a "multilocus model". Citing many papers in support, Baron (1996) found "negative or ambiguous results" for a locus predisposing to schizophrenia on chromosome 6 (6p24-22) (Diehl et al., 1994; Mowry et al., 1995; Gurling et al., 1995; Antonarakis et al., 1995; Riley et al., 1995; Sasaki et al., 1995; Moises et al., 1995b), but more recent work (Wang et al., 1996) presents evidence of linkage disequilibrium between schizophrenia and the SCA 1 CAG repeat on chromosome 6p23 (SCA1 = gene for spinocerebellar ataxia type 1). SCA1 may be of relevance to the etiology of schizophrenia, because anticipation occurs in this disease, because mutations occur via CAG repeat expansion, and also because of this gene's map location.

The pseudoautosomal locus which occupies a distal point on the short arms of the sex chromosomes and which is subject to $X Y$ recombination (the swapping of material between chromosomes during meiosis) has been proposed as a region genetically implicated in schizophrenia (Crow, 1988; Crow et al., 1989; DeLisi and Crow, 1989). Crow and colleagues based their results on finding aneuploid sex chromosomes (XXY, XYY and XXX) in schizophrenic patients and paternally inherited sexual concordance between schizophrenic sibling pairs. Similar results have been reported by Collinge et al. (1991), Gorwood et al. (1992) and D'Amato et al. (1992, 1994). The link between schizophrenic loci and the pseudoautosomal X-Y chromosome locus has not been confirmed because of difficulties in replicating the previous published data (Asherson et al., 1992; Wang et al., 1993; Barr et al., 1993; Curtis et al., 1993; Ishida et al., 1993; Wildenauer et al., 1993) and methodological uncertainties (Curtis and Gurling, 1990). Even so, it is important to emphasize that, in the work cited above, Collinge et al. (1991) tested Crow's hypothesis using marker DNA for the telomeric pseudoautosomal locus, DXYS14, and concluded that, as expected, schizophrenic sibling pairs shared alleles on the DXYS14 locus, supporting the existence of a genetic link between DXYS14 and schizophrenia - result confirmed by D'Amato et al. (1992, 1994). Nevertheless, due to the difficulties in replicating their previous experiments, Crow and colleagues revised their hypothesis and proposed a link with pericentromeric markers on the X-chromosome near the proximal pseudoautosomal limit (Crow et al., 1994; DeLisi et al., 1994a), which, while not supporting the hypothesis of the existence of locus for schizophrenia or schizoaffective disorder, "did not definitively exclude it" (Crow et al., 1994), reporting that their results were consistent with the presence of a gene predisposing to schizophrenia in "sex-specific regions" of the X- and Y-chromosomes. These findings were criticized in the detailed review by Baron (1995).

Okoro et al. (1995) did not find any experimental evidence for a link between the X-chromosome marker DXS7 and a schizophrenia locus, while Barr et al. (1994) also found 
no evidence in favor of a link between a locus predisposing to schizophrenia and the pseudoautosomal region. Even so, DeLisi et al. (1994b) included in their revision two group studies on samples of Swedish and American families reporting data suggesting that the frequency of XXX and XXY aneuploid sex-chromosomes was higher in populations of patients with schizophrenia, claiming that too few had survived to determine if an association also existed in respect to XYY chromosomes. These authors also concluded that this was consistent with a sex-chromosome gene influencing the development of schizophrenia and that a sex-chromosome locus is compatible with autosomic transmission if the gene was either pseudoautosomal (i.e., inside the recombination (exchange) region) or X-Y homologous (i.e., present in a similar form on both the $\mathrm{X}$ and $\mathrm{Y}$ chromosomes, with no recombination). The hypothesis of a "psychosis continuum" between schizophrenia and bipolar affective disorder defended by Crow (1988) led to work such as that done by Yoneda et al. (1992), who reported an association between bipolar affective disorder and a pseudoautosomal DNA marker (pseudoautosomal locus DXYS20), although the difference between patients and controls was not very significant and was not confirmed by other authors (Parsian and Todd, 1994). Straub et al. (1994) present strong evidence for a vulnerability locus for bipolar affective disorder on chromosome 21 (21q22.3).

Pulver et al. (1994a) reported that a gene predisposing to schizophrenia was present on chromosome 22 (22q12-q13.1), but they, and other workers, failed to replicate these findings in other studies (Coon et al., 1994; Pulver et al., 1994b). However, Moises et al. (1995a) reported a locus on the long arm of chromosome 22 (locus D22S278 at 22q12), suggesting the existence of an "oligogenic gene" in a multigenic system for schizophrenia. Schwab et al. (1995a) also succeeded in replicating Pulver's 1994 findings by using 4 microsatellite markers in region 22q12-q13.1 to study schizophrenia in 30 Israeli and German families, obtaining significant results for a dominant inheritance model for marker D22S304, suggesting that a "genetic factor" predisposing to schizophrenia occurs in region 22q12-q13.1 of chromosome 22. Vallada et al. (1995) found evidence favoring both Moises's D22S278 locus and locus D22S283 of chromosome 22, suggesting that these regions contain a gene contributing to the etiology of schizophrenia. To resolve once and for all this problem, Gill et al. (1996) developed an analysis combining genotypic data on the D22S278 marker alleles in multiple families affected with schizophrenia from 11 independent research groups throughout the world. This marker was chosen because it was the marker that demonstrated the most evidence of being linked to schizophrenia in 3 independent studies (Polymeropoulos et al., 1994; Lasseter et al., 1995; Vallada et al., 1995). The methodology used was "extended sib-pair (ESP) analysis" and a probability-based statistical analysis for sibling comparison. In the ESP analysis, using pairs of affected siblings with parents' genotypic data fully known, an excess of shared alleles was found in affected individuals. These results were statistically significant at the $\mathrm{P}=0.001$ level, indicating that there could be a schizophrenia susceptibility locus at chromosomal region 22q12.

In a study based on 571 schizophrenic patients (including those with schizo-affective disorder), ethnically paired with 639 controls and covering 7 European countries, Williams et al. (1996) proposed an association between schizophrenia and T102C polymorphism of the 5hydroxy-tryptamine (serotonin) type 2a-receptor gene (5$\mathrm{HT}_{2 \mathrm{a}}$ ) situated on the long arm of chromosome 13. These workers suggested that this gene, or a locus in linkage disequilibrium with it, conferred susceptibility to schizophrenia because the proportion of allele 2 and genotype $2 / 2$ of the T102C polymorphism was higher than expected in schizophrenic patients and was associated with the pathogenesis of this condition. Although similar results were observed in Japanese patients and controls (Inayama et al., 1996), the findings of Williams et al. have been criticized by various authors (Clifford and Nunez, 1996; Malhotra et al., 1996; Arranz et al., 1996; Sasaki et al., 1996; Crow, 1996). The investigations of Williams et al. and Inayama et al. were repeated in another study by Erdmann et al. (1996) who demonstrated that there was structural variability (2 amino-acid substitutions) in the human 5- $\mathrm{HT}_{2 \mathrm{a}}$ receptor but that receptor variants were encountered at similar frequencies in both schizophrenic individuals and normal controls, indicating that the presence of these variants were not etiologically related to schizophrenia. However, they also remarked that future studies might determine whether or not the 5- $\mathrm{HT}_{2 \mathrm{a}}$ receptor variants were associated with other pathological phenotypes or, as suggested by Propping and Nöthen (1995), had any pharmacogenetic relevance and that they had been able to replicate the findings of Williams $e t$ $a l$. and Inayama et al. in that there was an association between "non-coding T102C polymorphism" and the development of schizophrenia. Erdmann et al. also stated that even though $\mathrm{T} 102 \mathrm{C}$ polymorphism does not involve variation in the amino-acid sequence of the 5- $\mathrm{HT}_{2 \mathrm{a}}$ receptor (i.e, is non-coding), the association with schizophrenia could be explained by disequilibrium linkage with an unidentified functional variant occurring on a regulatory area of the gene. Lin et al. (1997) have suggested the existence of a potential schizophrenia susceptibility locus on chromosome 13 (13q14.1-q32) at markers D13S122 and D13S128, particularly in European families.

In a study on the metabolism of serotonin and the physiopathology of schizophrenia, using a polymerase chain reaction (PCR) product and restriction fragment length polymorphism (RFLP), Gelernter et al. (1995) proposed that schizophrenia and other neuropsychiatric disorders could be studied using the SLC6A4 locus of the gene for serotonin-transporting protein (occurring on chromosome 17 near region 17q12) and the D17S58 and D17S73 loci, because the localization of these loci was consistent with the observed crossovers. 
Persico et al. (1995) excluded a close link between schizophrenia spectrum disorders (SSD) and the dopamine transporter (DT) gene because allele variants at this locus did not contribute to schizophrenia. These authors used polymorphic markers for the DT gene in 156 subjects from 16 multiplex pedigrees exhibiting schizophrenia and SSD, and excluded a close link between the DT gene locus and SSD in both dominant and recessive models, thereby excluding a causal link between genetic mutations in the DT locus and phenotypic illness.

There has also been interest in the role played by the human D3 dopamine receptor (DRD3) gene (Giros et al., 1990) in the pathogenesis of schizophrenia. This gene was localized in region q13.3 of chromosome 3 by Le Coniat $e t$ al. (1991), but studies of the link between DRD3 polymorphisms and schizophrenia have consistently given negative results (Wiese et al., 1993; Coon et al., 1993a; Sabaté et al., 1994). In 2 independent association studies on French and British subjects, Crocq et al. (1992) found an excess of homozygotes for both BalI polymorphic DRD3 alleles (reflecting a deviation from Hardy-Weinberg equilibrium) in schizophrenic patients, suggesting that DRD3 could exercise a subtle influence on the predisposition to schizophrenia. These results were confirmed by Mant et al. (1994) as well as by Griffon et al. (1996), who worked with 119 chronic schizophrenics evaluated according to Diagnostic and Statistical Manual of Mental Disorders - III Edition, Revised (DSM-III-R) and 85 controls. But the work of Crocq et al. was not confirmed by other studies (Jönsson et al., 1993; Nöthen et al., 1993; Yang et al., 1993; Sabaté et al., 1994; Laurent et al., 1994).

In their revision, Portin and Alanen (1997) considered the numerous contradictory results and affirmed that "it seems that molecular genetic studies lend only minor support to the dopamine theory of schizophrenia", citing the many studies which had unsuccessfully tried to associate schizophrenia with genes for the dopamine D1, D2, D3, D4 and D5 receptors, as well as studies on other candidate genes such as the beta 1 GABA-A receptor gene (Asherson et al., 1991; Coon et al., 1993b). More recent studies by Tanaka et al. (1996) and Rothschild et al. (1996) have also failed to show an association between D2 and D3 receptors and schizophrenia, as have studies on Italian pedigrees by Grassi et al. (1996), who found no evidence for a link between schizophrenia and D2 receptor locus. However, Shaikh et al. (1996) have suggested an allelic association between schizophrenia and Ser-9-Gly polymorphism in the DRD3 gene.

With a view to finding an association between genetic variation and schizophrenia, genetic linkage studies have been made using the long arm of human chromosome 11 which contains the gene locus for the D2 dopamine receptor. Working with 5 Israeli families affected with multiple cases of schizophrenia, Mulcrone et al. (1995) used microsatellite dinucleotide DNA markers to examine the segregation of schizophrenia along chromosome 11q and, testing the hypothesis of linkage under genetic homogeneity of causation, found no linkage analysis evidence for significant causal mutations in the D11S420 delimited region of chromosome 11q13-24, although they considered the possibility that "a gene of major effect" exists in this region, either with low penetration or with heterogeneity. In a study of pedigrees from a region of eastern Quebec (extending up to the north of New Brunswick) densely affected with schizophrenia, Maziade et al. (1995) analyzed the link between schizophrenia and 11 microsatellite polymorphism CA repeat markers located at chromosomal region 11q21-22 containing the DRD2 gene for the D2 dopamine receptor. The diagnostic evaluation in cases of schizophrenia in probands and relatives was made through a consensus procedure using DSM-III-R, with the results showing no evidence in favor of a major gene effect influencing schizophrenia. Of the 4 families studied, the maximum lod score was 3.41 (for locus D11S35) in only one large family affected with schizophrenia, the authors concluding that this tendency to positive linkage in the pedigree which gave a significant lod score "may, or may not, reflect true linkage".

In one of six families in a multiplex study, Kosower et al. (1995) observed co-segregation of schizophrenia with Duffy blood group alleles and a variant of region $1 \mathrm{qH}$ of chromosome 1 containing the locus for pseudogene 2 (1q21.1) for the D5 dopamine receptor transcribed in normal lymphocytes. Consequently, in general, we see a growing preocupation in the literature with gene loci for dopamine and serotonin, alterations which are believed to be related to the physiopathology of schizophrenia.

More recently, a series of molecular genetic studies have continued to propose various loci which could be related to a predisposition to schizophrenia. In one study alone, involving 70 families with at least one chronic schizophrenic member, Shaw et al. (1998) proposed loci on 12 chromosomes $(1,2,4,5,8,10,11,12,13,14,16$ and 22) having at least one region potentially involved in schizophrenia. This linkage study used 388 markers spanning the genome all pedigrees, giving an average resolution of $10.5 \mathrm{cM}$ between 0 and $31 \mathrm{cM}$, and an average heterozygosity of $74.3 \%$ per marker. In 5 chromosomes $(1,2,4,11$ and 13) there was at least one marker with a lod score greater than 2.0, indicating heterogeneity. In another study, Schwab et al. (1998) provided support for a locus $0.5 \mathrm{cM}$ distal to the G-olfalpha (18p) region as conferring susceptibility to functional psychosis in families with schizophrenia. Genes in two regions of chromosome 18 (18p11.3 and 18q21.1) were also proposed as being involved in the genesis of schizophrenia and affective bipolar disorder, these results being very interesting because they suggest common genetic loci for these two psychosis, or, in other words, that these chromosome 18 loci are possibly not specific for schizophrenia (Mors et al., 1997). Defending the theory of commutative polygenes, Frota-Pessoa (1993) theorized that certain polygenes can favor the appearance of bipolar affective disorder as 
well as predisposing to schizophrenia, depending on the general influence of polygenes and environmental factors.

Other studies have proposed various loci predisposing to schizophrenia, including the work of Dann et al. (1997) on an X-chromosome locus at Xp11, of Morris-Rosendahl et al. (1997) on a tentative association between the gene for dentatorubral-pallidoluysian atrophy and schizophrenia on chromosome 12, of Freedman et al. (1997) on the 15q13-14 locus of chromosome 15 and of Deckert et al. (1997) on chromosome 22 at locus 22q12-13.

Various loci and regions have been cited for chromosome 6, including 6q13-q26 by Cao et al. (1997), D6S1960 on chromosome 6p by Brzustowicz et al. (1997), D6S274 and D6S285 on 6p by Turerki et al. (1997), 6p23p24 by Olavesen et al. (1997), 6p22-24 by Pujana et al. (1997) and 6p24-22 with markers D6S296 and D6S277 by Maziade et al. (1997), who again raised the hypothesis that this locus may be a common locus for both schizophrenia and affective bipolar disorder. The work on chromosome 6p at the HLA-DRB1 (6p21.3) locus by Wright et al. $(1996,1998)$ and the HLA-DQB1 locus by Grobetakopf et al. (1998) focused on the role of the human leukocyte antigen (HLA) complex and the autoimmune theory of schizophrenia.

Even the loci on chromosomes 6 and 22, most cited in this paper as probably involved in modulating susceptibility to schizophrenia, have not shown evidence of linkage in some more recent publications. Cao et al. (1997) were not able to confirm previous reports of linkage with the short arm of chromosome 6 (6p), while two other studies (Garner et al., 1996; Daniels et al., 1997) found no linkage between schizophrenia and the 6p24-22 region. Parsian et al. (1997) were not able to replicate the findings of Pulver $e t$ al. (1994a) and obtained no evidence of linkage between schizophrenia and 22q12, thus excluding all the region between the D22S268 and D22S307 markers. Working with South-African Bantu families affected with schizophrenia, Riley et al. (1996) found no evidence of linkage with markers on chromosome 22. However, using a dominant inheritance model and marker D22S303, Lachman et al. (1997) suggested a possible locus for bipolar disorder near the velo-cardio-facial syndrome region of chromosome 22 (22q11), and obtained a maximum lod score of 2.51 in families affected with this condition. As has been stated earlier in this revision, Schwab et al. (1995a) suggested a locus for schizophrenia at 22q12-q13.1, obtaining significant results for the same type of inheritance with marker D22S304. In other words, two loci situated close together on the same chromosome and sharing the same dominant inheritance model have been proposed for two psychosis.

Mowry et al. (1997) revised various findings related to chromosomes $3,6,8,13,18,22$ and the $\mathrm{X}$-chromosome, and concluded that the experimental evidence pointed to the loci 6p24-22, 8p22-21 and 22q12-q13.1 as being responsible for susceptibility to schizophrenia. These authors also considered that in the light of the molecular genetics findings available, schizophrenia was a "genetically complex disease with an unclear mode of transmission".

To conclude this critical revision of a decade of studies on the molecular genetics involved in the search for genes modulating the predisposition to schizophrenia, we can summarize as follows:

1. Even though a great number of studies using sophisticated molecular biology techniques have been published and many loci, involving more than half the chromosome complement, have been suggested which may predispose to schizophrenia, neither its genetic locus nor its exact mode of transmission is known.

2 . The most cited loci correspond to chromosomal regions 6p24-22 and 22q12-13.

3 . The more recent literature is most concerned with human gene loci for the receptors for the neurotransmitters dopamine and serotonin, which are potentially involved in the physiopathology of schizophrenia.

4 . Work on some more recently implicated loci on chromosomes 6, 18 and 22 suggests that there may exist genetic loci which are not specific for schizophrenia, but which can also predispose to other psychosis such as bipolar disorder.

5. More recently published work on the chromosome 6 locus for human leukocyte antigen complex points to an autoimmune theory for schizophrenia.

6 . The highly variable results in the published research suggest that multiple loci are involved in the predisposition to schizophrenia, pointing to heterogeneity which, as was discussed earlier in this revision, is more polygenic (various genes acting together) than monogenic (a different gene for each family).

\section{ACKNOWLEDGMENTS}

Publication supported by FAPESP.

RESUMO

A genética da esquizofrenia (como também do distúrbio bipolar) teve grande avanço a partir da descoberta, a nível de genética molecular, da técnica de localização de genes com uso de sondas de DNA (Botstein et al., 1980). Os estudos que procuram "genes candidatos" a exercerem algum papel na susceptibilidade à esquizofrenia são, basicamente, de dois tipos: de ligação ("linkage") e de associação. Quando, à luz da genética molecular, um gene é localizado próximo a um marcador de DNA específico no cromossomo, fala-se em estudo "de ligação". Por outro lado, quando a doença é associada a um alelo específico de um determinado gene, fala-se em estudo "de associação". Esta revisão cobriu uma década de publicações sobre o assunto, desde os primeiros trabalhos de Bassett et al. e de Sherrington et al., ambos divulgados em 1988 (gene localizado no braço longo do cromossomo 5, loco em "5q11-13") até as recentes propostas de Lin et al. (1997), apontando para o loco "13q14.1-q32" no cromossomo 13 e de Wright et al. (1998) para o loco genético "HLA DRB1" no nível de "6p21.3" no cromossomo 6. Os locos mais replicados foram: no braço longo do cromossomo 22 ("22q12-q13.1”) e no braço 
curto do cromossomo 6 (“6p24-22"). Nesta revisão crítica de estudos sobre genética molecular envolvidos na localização de genes que modulam a predisposição à esquizofrenia, observou-se grande variabilidade nos resultados, sugerindo múltiplos locos envolvidos na predisposição à doença.

\section{REFERENCES}

Antonarakis, S.E., Blouin, J.-L., Pulver, A.E. et al. (1995). Schizophrenia susceptibility and chromosome 6p24-22. Nat. Genet. 11: 235-236.

Arranz, M.J., Lin, M.-W., Powell, J. et al. (1996). 5HT-2a receptor T102C polymorphism and schizophrenia. Lancet 347: 1831-1832.

Asherson, P., Mant, R., Sargeant, M. et al. (1991). Exclusion of close linkage between GABA-A receptor subunit $1 \mathrm{~A}$ gene and schizophrenia using a microsatellite repeat marker. Clin. Genet. 40: 400.

Asherson, P., Parfitt, E., Sargeant, M. et al. (1992). No evidence for a pseudoautosomal locus for schizophrenia. Br. J. Psychiatry 161: 63-68.

Baron, M. (1995). Genes and psychosis: old wine in new bottles? Acta Psychiatr. Scand. 92: 81-86.

Baron, M. (1996). Linkage results in schizophrenia. Am. J. Med. Genet. 67: $121-123$

Barr, C.L., Kennedy, J.L., Pakstis, A.J. et al. (1993). Exclusion of a major susceptibility locus in the pseudoautosomal region in a large Swedish Kindred. Schizophr. Res. 9: 115

Barr, C.L., Kennedy, J.L., Pakstis, A.J. et al. (1994). Linkage study of a susceptibility locus for schizophrenia in the pseudoautosomal region. Schizophr. Bull. 20: 277-286.

Bassett, A.S., McGillivray, B.C., Jones, B.D. and Pantzar, J.T. (1988). Partial trisomy of chromosome 5 cosegregating with schizophrenia. Lancet I: 799-801.

Botstein, D., White, R.L., Skolnick, M. and Davis, R.W. (1980). Construction of a genetic linkage map in man using restriction fragment length polymorphism. Am. J. Hum. Genet. 32: 314-331.

Brzustowicz, L.M., Honer, W.G., Chow, E.W.C., Hogan, J., Hodgkinson, K. and Bassett, A.S. (1997). Use of a quantitative trait to map a locus associated with severity of positive symptoms in familial schizophrenia to chromosome 6p. Am. J. Hum. Genet. 61: 1388-1396.

Cao, Q., Martinez, M., Zhang, J., Sanders, A.R., Badner, J.A., Cravchik, A., Markey, C.J., Beshah, E., Guroff, J.J., Maxwell, M.E., Kazuba, D.M., Whiten, R., Goldin, L.R., Gershon, E.S. and Gejman, P.V. (1997). Suggestive evidence for a schizophrenia susceptibility locus on chromosome $6 \mathrm{q}$ and a confirmation in an independent series of pedigrees. Genomics 43: 1-8.

Clifford, C.P. and Nunez, D.J.R. (1996). 5HT- ${ }_{2 \mathrm{a}}$ receptor T102C polymorphism and schizophrenia. Lancet 347: 1830.

Collinge, J., DeLisi, L.E., Boccio, E. et al. (1991). Evidence for a pseudoautosomal locus for schizophrenia using the method of affected sibling pairs. Br. J. Psyschiatry 158: 624-629.

Coon, H., Byerley, W., Holik, J. et al. (1993a). Linkage analysis of schizophrenia with five dopamine receptor genes in nine pedigrees. Am. J. Hum. Genet. 52: 327-334.

Coon, H., Sobell, J., Heston, L. et al. (1993b). Search for mutations in the beta-1 GABA-A receptor subunit gene in patients with schizophrenia. Am. J. Med. Genet. 54: 12-20.

Coon, H., Holink, J., Hoff, M. et al. (1994). Analysis of chromosome 22 markers in nine schizophrenia families. Am. J. Med. Genet. 54: 72-79.

Crocq, M.A., Mant, R., Asherson, P. et al. (1992). Association between schizophrenia and homozygosity at the dopamine D3 receptor gene. J. Med. Genet. 29: 858-860.

Crow, T.J. (1988). Sex chromosomes and psychosis: the case for a pseudoautosomal locus. Br. J. Psychiatry 153: 675-683.

Crow, T.J. (1996). 5HT- ${ }_{2 \mathrm{a}}$ receptor T102C polymorphism and schizophrenia. Lancet 347: 1832.

Crow, T.J., DeLisi, L.E. and Johnstone, E.C. (1989). Concordance by sex in sibling pairs with schizophrenia is paternally inherited: evidence for a pseudoautosomal locus. Br. J. Psychiatry 155: 92-97.

Crow, T.J., DeLisi, L.E., Lofthouse, R. et al. (1994). An examination of linkage of schizophrenia and schizoaffective disorder to the pseudoautosomal region (Xp22.3). Br. J. Psychiatry 164: 159-164.
Curtis, D. and Gurling, H. (1990). Unsound methodology in investigating a pseudoautosomal locus in schizophrenia. Br. J. Psychiatry 165: 415-416.

Curtis, D., Kalsi, G., Brynjolfsson, J. et al. (1993). Investigation by linkage analysis of the XY chromosomal region in the genetic susceptibility to schizophrenia. Psychiatr. Genet. 3: 125-126.

D'Amato, T., Campion, D., Gorwood, P.H. et al. (1992). Evidence for a pseudoautosomal locus for schizophrenia. II. Replication of a nonrandom segregation of alleles at the DXYS14 locus. Br. J. Psychiatry 161: 59-62.

D’Amato, T., Waksman, G., Martinez, M. et al. (1994). Pseudoautosomal region in schizophrenia: linkage analysis of seven loci by sib-pair and lod-score methods. Psychiatr. Res. 52: 135-147.

Daniels, J.K., Spurlock, G., Williams, N.M., Cardno, A.G., Jones, L.A., Murphy, K.C., Asherson, P., Holmans, P., Fenton, I., McGuffin, P. and Owen, M.J. (1997). Linkage study of chromosome 6p in sib-pairs with schizophrenia. Am. J. Med. Genet. 74: 319-323.

Dann, J., DeLisi, L.E., Devoto, M., Laval, S., Nancarrow, D.J., Shields, G., Smith, A., Loftus, J., Peterson, P., Vita, A., Comazzi, M., Invernizzi, G., Levinson, D.F., Wildenauer, D., Mowry, B.J., Collier, D., Powell, J., Crowe, R.R., Andreasen, N.C., Silverman, J.M., Mohs, R.C., Murray, R.M., Walters, M.K., Lennon, D.P., Hayward, M.K., Albus, M., Lerer, B., Maier, W. and Crow, T.J. (1997). A linkage study of schizophrenia to markers within Xpll near the MAOB gene. Psychiatr. Res. 70: 131-143.

Deckert, J., Nothen, M.M., Bryant, S.P., Schuffenhauer, S., Schofield, P.R., Spurr, N.K. and Propping, P. (1997). Mapping of the human adenosine A-2a receptor gene: Relationship to potential schizophrenia loci on chromosome 22q and exclusion from the CATCH 22 region. Hum. Genet. 99: 326-328.

DeLisi, L.E. and Crow, T.J. (1989). Evidence for a sex chromosome locus for schizophrenia. Schizophr. Bull. 15: 431-440.

DeLisi, L.E., Devoto, M., Lofthouse, R. et al. (1994a). Search for linkage to schizophrenia in the X and Y chromosomes. Am. J. Med. Genet. 54: 113121

DeLisi, L.E., Friedrich, U., Wahlstrom, J. et al. (1994b). Schizophrenia and sex chromosome anomalies. Schizophr. Bull. 20: 495-505.

Diehl, S.R., Wang, S., Detera-Wadleigh, S. et al. (1994). Evidence suggesting possible SCA1 gene involvement in schizophrenia. Am. J. Hum. Genet. 55 (Suppl.): 867.

Erdmann, J., Shimbron-Abardanell, D., Rietschel, M. et al. (1996). Systematic screening for mutations in the human serotonin-2A (5-HT-2A) receptor gene: identification of two naturally occurring receptor variants and association analysis in schizophrenia. Hum. Genet. 97: 614-619.

Freedman, R., Coon, H., Myles-Worsley, M., Orr-Urtreger, A., Olincy, A., Davis, A., Polymeropoulos, M., Holik, J., Hopkins, J., Hoff, M., Rosenthal, J., Waldo, M.C., Reimherr, F., Wender, P., Yaw, J., Young, D.A., Breese, C.R., Adams, C., Patterson, D., Adler, L.E., Kruglyak, L., Leonard, S. and Byerley, W. (1997). Linkage of a neurophysiological deficit in schizophrenia to a chromosome 15 locus. Proc. Natl. Acad. Sci. USA 94: 587-592.

Frota-Pessoa, O. (1989). Genética da Esquizofrenia. J. Bras. Psiquiatr. 38: 184-193.

Frota-Pessoa, O. (1993). Genética. In: Esquizofrenia - Atualização em Diagnóstico e Tratamento (Caetano, D., Frota-Pessoa, O. and Bechelli, L.P.C., eds.). Livraria Atheneu Editora, São Paulo, pp. 105-133.

Garner, C., Kelly, M., Cardon, L., Joslyn, G., Carey, A., Leduc, C., Lichter, J., Harris, T., Loftus, J., Shields, G., Comazzi, M., Vita, A., Smith, A.M., Dann, J., Crow, T.J. and DeLisi, L.E. (1996). Linkage analysis of schizophrenia to chromosome 6p24-p22: An attempt to replicate. Am. J. Med. Genet. 67: 595-610.

Gelernter, J., Pakstis, A.J. and Kidd, K.K. (1995). Linkage mapping of serotonin transporter protein gene SLC6A4 on chromosome 17. Hum. Genet. 95: 677-680

Gill, M., Vallada, H., Collier, D. et al. (1996). A combined analysis of D22S278 marker alleles in affected sib-pairs: support for a susceptibility locus for schizophrenia at chromosome 22q12. Am. J. Med. Genet. (Neuropsychiatr. Genet.) 67: 40-45.

Giros, B., Martres, M.P, Sokoloff, P. and Shwartz, J.C. (1990). cDNA cloning of the human dopaminergic D3 receptor and chromosome identification. C.R. Acad. Sci. 311: 501-508.

Gorwood, P., LeBoyer, M., D'Amato, T. et al. (1992). Evidence for a pseudoautosomal locus for schizophrenia. I. A replication study using phenotype analysis. Br. J. Psychiatry 161: 55-58. 
Grassi, E., Mortilla, M., Amaducci, L. et al. (1996). No evidence of linkage between schizophrenia and D2 dopamine receptor gene locus in Italian pedigrees. Neurosci. Lett. 206: 196-198.

Griffon, N., Croq, M.A., Pilon, C. et al. (1996). Dopamine D3 receptor gene: organization, transcript variants, and polymorphism associated with schizophrenia. Am. J. Med. Genet. (Neuropsychiatr. Genet.) 67: 63-70.

Grobetakopf, A., Mueller, N., Malo, A. and Wank, R. (1998). Potencial role for the narcolepsy- and multiple sclerosis-associated HLA allele DQB1*0602 in schizophrenia subtypes. Schizophr. Res. 30: 187-189.

Gurling, H. (1994). Genetic linkage analysis: a critical appraisal of the resolution of heterogeneity in the schizophrenias. In: Genetic Approaches to Mental Disorders (Gershon, E.S. and Cloninger, C.R., eds.). American Psychiatric Press, Washington, DC, pp. 231-252.

Gurling, H., Kalsi, G., Hui-Sui Chen, A. et al. (1995). Schizophrenia susceptibility and chromosome 6p24-22. Nat. Genet. 11: 234-235.

Hallmayer, J., Maier, W., Ackenheil, M. et al. (1992). Evidence against linkage of schizophrenia to chromosome 5q11-5q13 markers in systematically ascertained families. Biol. Psychiatry 31: 83-94.

Inayama, Y., Yoneda, H., Sakai, T. et al. (1996). Positive association between a DNA sequence variant in the serotonin $2 \mathrm{~A}$ receptor gene and schizophrenia. Am. J. Med. Genet. (Neuropsychiatr. Genet.) 67: 103-105.

Ishida, T., Yoneda, H., Sakai, T. et al. (1993). Pseudoautosomal region in schizophrenia-sex concordance of the affected sib-pairs and association study with DNA markers. Am. J. Med. Genet. 48: 151-155.

Jönsson, E., Lannfelt, L., Sokoloff, P. et al. (1993). Lack of association in a BalI polymorphism in the dopamine D3 receptor gene in schizophrenia. Acta Pychiatr. Scand. 87: 345-347.

Kendler, K.S., MacLean, C.J., O'Neill, F.A., Burke, J., Murphy, B., Duke, F., Shinkwin, R., Easter, S.M., Webb, B.T., Zhang, J., Walsh, D. and Straub, R.E. (1996). Evidence for a schizophrenia vulnerability locus on chromosome 8p in the Irish Study of High-Density Schizophrenia Families. Am. J. Psychiatry 153: 1534-1540.

Kosower, N.S., Gerad, L., Goldstein, M. et al. (1995). Constitutive heterochromatin of chromosome 1 and Duffy blood group alleles in schizophrenia. Am. J. Med. Genet. 60: 133-138.

Lachman, H.M., Kelsoe, J.R., Remick, R.A., Dessa-Sadovnick, A., Rapaport, M.H., Lin, M., Pazur, B.A., Roe, A.M.A., Saito, T. and Papolos, D.F. (1997). Linkage studies suggest a possible locus for bipolar disorder near the velo-cardio-facial syndrome region on chromosome 22. Am. $J$. Med. Genet. 74: 121-128.

Lasseter, V.K., Pulver, A.E., Wolnyiec, P.S. et al. (1995). Follow-up report of potential linkage on chromosome 22q: Part 3. Am. J. Med. Genet. (Neuropsychiatr. Genet.) 60: 172-173.

Laurent, C., Savoye, C., Samolyk, D. et al. (1994). Homozygosity at the D3 receptor locus is not associated with schizophrenia. J. Med. Genet. 31: 260-264.

Le Coniat, M., Sokoloff, P., Hillion, J. et al. (1991). Chromosomal localization of the human D3 dopamine receptor gene. Hum. Genet. 87: 618-620.

Lin, M.W., Sham, P., Hwu, M.G., Gollier, D., Murray, R. and Powell, J.F. (1997). Suggestive evidence for linkage of schizophrenia to markers on chromosome 13 in Caucasian but not Oriental populations. Hum. Genet. 99: 417-420

Macciardi, F., Kennedy, J.L., Ruocco, L. et al. (1992). A genetic linkage study of schizophrenia to chomosome 5 markers in a northern Italian population. Biol. Psychiatry 31: 720-728.

Malhotra, A.K., Goldman, D., Buchanan, R., Breier, A. and Pichar, D. (1996) 5HT-2a receptor T102C polymorphism and schizophrenia. Lancet 347: 1830-1831.

Mant, R., Williams, J., Asherson, P., Parfitt, E., McGuffin, P. and Owen, M.J. (1994). The relationship between homozygosity at the dopamine D3 receptor gene and schizophrenia. Am. J. Med. Genet. 54: 21-26

Maziade, M., Raymond, V., Cliche, D. et al. (1995). Linkage results on 11q2122 in Eastern Quebec pedigrees densely affected by schizophrenia. Am. J. Med. Genet. 60: 522-528

Maziade, M., Bissonnette, L., Rouillard, E., Martinez, M., Turgeon, M., Charron, L., Pouliot, V., Boutin, P., Cliche, D., Dion, C., Fournier, J.P., Garneau, Y., Lavallee, J.C., Montgrain, N., Nicole, L., Pires, A., Ponton, A.M., Potvin, A., Wallot, H., Roy, M.A., Groupe-Irep and Merette, C. (1997). 6p24-22 Region and major psychoses in the eastern Quebec population. Am. J. Med. Genet. 74: 311-318.

Moises, H.W., Yang, L., Li, T. et al. (1995a). Potential linkage disequilibrium between schizophrenia and locus D22S278 on the long arm of chromosome 22. Am. J. Med. Genet. 60: 465-467.

Moises, H.W., Yang, L., Kristbjarnarson, H. et al. (1995b). An international two-stage genome-wide search for schizophrenia susceptibility genes. Nat. Genet. 11: 321-324.

Morris-Rosendahl, D.J., Burgert, E., Uyanik, G., Mayerova, A., Duval, F., Macher, J.P. and Crocq, M.A. (1997). Analysis of the CAG repeats in the SCA1 and B37 genes in schizophrenic and bipolar I disorder patients: Tentative association between B37 and schizophrenic Am. J. Med. Genet. 74: 324-330.

Mors, O., Ewald, M., Blackwood, D. and Muir, W. (1997). Cytogenetic abnormalities on chromosome 18 associated with bipolar affective disorder or schizophrenia. Br. J. Psychiatry 170: 278-280.

Mowry, B.J., Mancarrow, D.J., Lennon, D.P. et al. (1995). Schizophrenia susceptibility and chromosome 6p24-22. Nat. Genet. 11: 233-234.

Mowry, B.J., Mancarrow, D.J. and Levinson, D.F. (1997). The molecular genetics of schizophrenia: An update. Aust. N. Z. J. Psychiatry 31: 704 713.

Mulcrone, J., Whatley, S.A., Marchbanks, R. et al. (1995). Genetic linkage analysis of schizophrenia using chromosome 11q13-24 markers in Israeli pedigrees. Am. J. Med. Genet. 60: 103-108.

Nöthen, M.M., Körner, J., Lannfelt, L. et al. (1993). Lack of association between schizophrenia and alleles of the dopamine D1, D2, D3 and D4 receptor loci. Arch. Gen. Psychiatr. Genet. 3: 89-94.

Okoro, C., Bell, R., Sham, P. et al. (1995). No evidence for linkage between the X-chromosome marker DXS7 and schizophrenia. Am. J. Med. Genet. 60: 461-464

Olavesen, M.G., Bentley, E., Mason, R.V.F., Stephens, R.J. and Ragoussis, J. (1997). Fine mapping of 39 ESTs on human chromosome 6p23-p25. Genomics 46: 303-306.

Parsian, A. and Todd, R.D. (1994). Bipolar disorder and the pseudoautosomal region. An association study. Am. J. Med. Genet. 54: 5-7.

Parsian, A., Suarez, B.K., Isenberg, K., Hampe, C.L., Fisher, L., Chakraverty, S., Meszaros, K., Lenzinger, E., Willinger, U., Fuchs, K., Aschauer, H.N. and Cloninger, C.R. (1997). No evidence for a schizophrenia susceptibility gene in the vicinity of IL2RB on chromosome 22. Am. J. Med. Genet. 74: 361-364.

Persico, A.M., Wang, Z.W., Black, D.W., Andreasen, N.C., Uhl, G.R. and Crowe, R.R. (1995). Exclusion of close linkage of the dopamine transporter gene with schizophrenia spectrum disorders. Am. J. Psychiatry 152: $134-136$

Polymeropoulos, M.H., Coon, H., Byerley, W. et al. (1994). Search for a schizophrenia susceptibility locus on chromosome 22. Am. J. Med. Genet. 54: 93-99.

Portin, P. and Alanen, Y.O. (1997). A critical review of genetic studies of schizophrenia. II. Molecular genetic studies. Acta Psychiatr. Scand. 95: 73-80.

Propping, P. and Nöthen, M.M. (1995). Genetic variation of CNS receptors - a new perspective for pharmacogenetics. Pharmacogenetics 5: 318-325.

Pujana, M. A., Martorell, L., Volpini, V., Valero, J., Labad, A., Vilella, E. and Estivill, X. (1997). Analysis of amino-acid and nucleotide variants in the spinocerebellar ataxia type 1 (SCA1) gene in schizophrenic patients. Hum. Genet. 99: 772-775.

Pulver, A.E., Karayiorgou, M., Wolniec, P.S. et al. (1994a). Sequential strategy to identify a susceptibility gene for schizophrenia: report of potential linkage on chromosome 22q12-q13.1: Part 1.Am. J. Med. Genet. 54: 36-43

Pulver, A.E., Karayiorgou, M., Lasseter, V.K. et al. (1994b). Follow-up of a report of a potential linkage for schizophrenia on chromosome 22q12q13.1: Part 2. Am. J. Med. Genet. 54: 44-50.

Pulver, A.E., Lasseter, V.K., Kasch, L. et al. (1995). Schizophrenia: A genome scan targets chromosomes $3 p$ and $8 p$ as potential sites of suceptibility genes. Am. J. Med. Genet. 60: 252-260.

Riley, B.P., Mogudi-Carter, M., Rajagopalan, S., Jenkins, T. and Williamson, R. (1995). No evidence for linkage of schizophrenia to the short arm of chromosome 6 in a sample of southern African Bantu-speaking families. Am. J. Hum. Genet. (Suppl.) 57: 1158

Riley, B., Mogudi-Carter, M., Jenkins, T. and Williamsom, R. (1996). № evidence for linkage of chromosome 22 markers to schizophrenia in southern African Bantu-speaking families. Am. J. Med. Genet. 67: 515-522.

Riley, B.P., Tahir, E., Rajagopalan, S., Mogudi-Carter, M., Faure, S., 
Weissenbach, J., Jenkins, T. and Williamson, R. (1997). A linkage study of the N-methyl-D-aspartate receptor subunit gene loci and schizophrenia in southern African Bantu-speaking families. Psychiatr. Genet. 7:57-74

Risch, N. (1990). Linkage strategies for genetically complex traits - 1. Multilocus models. Am. J. Hum. Genet. 46: 229-241.

Rothschild, L.G., Badner, J., Cravchik, A., Gershon, E.S. and Gejman, P.V. (1996). No association detected between a D3 receptor gene-expressed variant and schizophrenia. Am. J. Med. Genet. (Neuropsychiatr. Genet.) 67: 232-234.

Sabaté, O., Campion, D., D'Amato, T. et al. (1994). Failure to find evidence for linkage or association between the dopamine D3 receptor gene and schizophrenia. Am. J. Psychiat. 151: 107-111.

Sasaki, T., Bassett, A.S., Horner, W.G. et al. (1995). Evaluation of markers at 6p21-23 in eastern Canadian schizophrenic families. Am. J. Hum. Genet. (Suppl.) 57: 1165.

Sasaki, T., Hattori, M., Fukuda, R., Kunugi, H. and Nanko, S. (1996). 5HT2a receptor T102C polymorphism and schizophrenia. Lancet 347: 1832.

Schwab, S.G., Albus, M., Hallmayer, J. et al. (1995a). Evaluation of a susceptibility gene for schizophrenia on chromosome $6 p$ by multipoint affected sib-pair linkage analysis. Nat. Genet. 11:325-327.

Schwab, S.G., Lerer, B., Albus, M. et al. (1995b). Potential linkage for schizophrenia on chromosome 22q12-q13: a replication study. Am. J. Med. Genet. 60: 436-443.

Schwab, S.G., Hallmayer, J., Lerer, B., Albus, M., Borrmann, M., Honing, S., Strauss, M., Segman, R., Lichtermann, D., Knapp, M., Trixler, M., Maier, W. and Wildenauer, D.B. (1998). Support for a chromosome 18p locus conferring susceptibility to functional psychoses in families with schizophrenia, by association and linkage analysis. Am. J. Hum. Genet. 63: 1139-1152

Shaikh, S., Collier, D.A., Sham, P.C., Ball, D., Aitchison, K., Vallada, H., Smith, I., Gill, M. and Kerwin, R.W. (1996). Allelic association between a Ser-9-Gly polymorphism in the dopamine D3 receptor gene and schizophrenia. Hum. Genet. 97: 714-719.

Shaw, S.H., Kelly, M., Smith, A.B., Shields, G., Hopkins, P.J., Loftus, J., Laval, S.H., Vita, A., De-Hert, M., Cardon, L.R., Crow, T.J., Sherrington, R. and DeLisi, L.E. (1998). A genome-wide search for schizophrenia susceptibility genes. Am. J. Med. Genet. 81: 364-376.

Sherrington, R., Brynjolfsson, J. Petursson, H., Potter, M., Dudleston, K., Barraclough, B., Wasmuth, J., Dobbs, M. and Gurling, H. (1988). Localization of a susceptibility locus for schizophrenia on chromosome 5 . Nature 336: 164-167.

Silverman, J.M., Greenberg, D.A., Altstiel, L.D. et al. (1996). Evidence of a locus for schizophrenia and related disorders on the short arm of chromosome 5 in a large pedigree. Am. J. Med. Genet. (Neuropsychiatr. Genet.) 67: 162-171.

Straub, R.E., Lehner, T., Luo, Y. et al. (1994). A possible vulnerability locus for bipolar affective disorder on chromosome 21q22.3. Nat. Genet. 8: 291-296
Straub, R.E., MacLean, C.J., O’Neill, F.A. et al. (1995). A potential vulnerability locus for schizophrenia on chromosome 6p24-22: evidence for genetic heterogeneity. Nat. Genet. 11: 287-293.

Tanaka, T., Igarashi, S., Onodera, O., Tanaka, H., Fukushima, N., Takahashi, M., Kameda, K., Tsuji, S. and Ihda, S. (1996). Lack of association between dopamine D2 receptor gene Cys311 variant and schizophrenia. Am. J. Med. Genet. (Neuropsychiatr. Genet. ) 67: 208-211.

Turerki, G., Rouleau, G.A., Joober, R. et al. (1997). Schizophrenia and chromosome 6p. Am. J. Med. Genet. 74: 195-198.

Vallada, H.P., Gill, M., Sham, P., Lim, L.C., Nanko, S., Asherson, P., Murray, R.M., McGuffin, P., Owen, M.J. and Collier, D. (1995). Linkage studies on chromosome 22 in familial schizophrenia. Am. J. Med. Genet. 60: 139146.

Wang, S., Sun, C.-e, Walczak, C.A., Ziegle, J.S., Kipps, B.R., Goldin, L.R. and Diehl, S.R. (1995). Evidence for a susceptibility locus for schizophrenia on chromosome 6pter-p22. Nat. Genet. 10:41-46.

Wang, S., Detera-Wadleigh, S.D., Coon, H., Sun, C., Goldin, L.R., Duffy, D.L., Byerley, W.F., Gershon, E.S. and Diehl, S.R. (1996). Evidence of linkage disequilibrium between schizophrenia and the SCA1 CAG repeat on chromosome 6p23. Am. J. Hum. Genet. 59: 731-736.

Wang, Z.W., Black, D., Andreasen, N. and Crowe, R.R. (1993). Pseudoautosomal locus for schizophrenia excluded in 12 pedigrees. Arch. Gen. Psychiatry 50: 199-204.

Wiese, C., Lannfelt, L., Kristbjarnarson, H. et al. (1993). No linkage between schizophrenia and D3 dopamine receptor gene locus in Icelandic pedigrees. Psychiatr. Res. 46: 253-259.

Wildenauer, D.B., Schwab, S.G., Wurl, D. et al. (1993). Linkage studies in psychiatric disorders. Psychiatr. Genet. 3: 127.

Williams, J., Spurlock, G., McGuffin, P., Mallet, J., Nothen, M.M., Gill, M., Aschauer, H., Nylander, P.-O., Macciardi, F. and Owen, M.J. (1996). Association between schizophrenia and $\mathrm{T} 102 \mathrm{C}$ polymorphism of the 5hydroxy-tryptamine type 2a-receptor gene. Lancet 347: 1294-1296.

Wright, P., Donaldson, P.T., Underhill, J.A., Choudhuri, K., Doherty, D.G. and Murray, R.M. (1996) Genetic association of the HLA DRB1 gene locus on chromosome 6p21.3 with schizophrenia. Am. J. Psychiatry 153: 1530-1533.

Wright, P., Dawson, E., Donaldson, P.T., Underhill, J.A., Sham, P.C., Zhao, J., Gill, M., Nanko, S., Owen, M.J., McGuffin, P. and Murray, R.M. (1998). A transmission/disequilibrium study of the DBR $1 * 04$ gene locus on chromosome 6p21.3 with schizophrenia. Schizophr. Res. 32: 75-80.

Yang, L., Li, T., Wiese, C., Lannfelt, L., Sokoloff, P., Xu, C.T., Zeng, Z., Schwartz, J.C., Liu, X. and Moises, H.W. (1993). No association between schizophrenia and homozigosity at the D3 dopamine receptor gene. Am. J. Med. Genet. (Neuropsychiatr. Genet.) 48: 83-86.

Yoneda, H., Sakai, T., Ishida, T. et al. (1992). An association between manicdepressive illness and a pseudoautosomal DNA marker. Am. J. Hum. Genet. 51: 1172-1173.

(Received July 5, 2000) 